\title{
Customers' Switching Barrier on Switching Behavior from Conventional Banks to Sharia Banks
}

\author{
Kasnaeny Karim ${ }^{\mathrm{a}, *}$, Ibrabim Dani ${ }^{\mathrm{a}}$ \\ ${ }^{a}$ Universitas Muslim Indonesia
}

\begin{abstract}
This study aims to explore the reasons why conventional bank customers have not yet shifted to Islamic (sharia) banking in South Sulawesi, as well as identify the obstacles that have caused customers to remain conventional banks. The research subjects numbered 110 people. The research method uses Mixed Methods with sequential exploratory design. The first stage is a qualitative method to obtain data that is variable because the community has not yet switched to sharia banking. The second stage of the quantitative method is using factor analysis, to deepen the data and test the data so that the findings can be generalized. Data were collected by open and closed questionnaires and interviews, validity, and reliability tests were carried out based on the analysis model used. The results of the analysis show that the factors that constrain people to move to sharia banking are fee interest factor, information factor, location factor, relationship and reputation factor, religiosity factor, product factor, and financial risk cost factor. There are four findings of new factors as the novelty of this study, namely fee interest factor, location factor, religiosity factor, and product factor, as barriers to switching for the service industry, especially sharia banking.
\end{abstract}

Keywords: behavior model, switching barrier, switching behavior, sharia bank and conventional bank

\section{INTRODUCTION}

Competition in the banking world today, not only between conventional banks but the presence of Islamic (sharia) banks in 1991 and officially operating in 1992 (Hastuti, 2019), makes competition between conventional banks and Islamic Bank (sharia Bank). Thus, the public has many choices in using banking services. The presence of sharia banking is expected to be able to reach a large number of customers, given the majority of Indonesian people are Muslim. In addition, it is considered to be able to meet the need for a sense of security for Muslims, primarily avoiding the existence of sins due to usury. Data from the Central Statistics Agency (BPS) in 2010, there were 207,176,162 Muslim communities in Indonesia, the percentage was $87.18 \%$. The growth of Islamic banking is expected to be very fast when these Muslim communities can unite to use Islamic banking.

But in reality, the growth of sharia bank customers is not as expected. The phenomenon that is seen, people in Indonesia, especially in South Sulawesi, are still less interested in moving

\footnotetext{
*Author in correspondence,

Email address: kasnaeny@umi .ac.id (Kasnaeny Karim)
}

to sharia banks. sharia banking market share did not experience a significant increase. The national banking map is based on information from Bank Indonesia as of October 2013, Islamic banking has a market share of 4.8 percent. Meanwhile, there are 12 million third-party fund accounts, or 9.2 percent of the total national banking accounts. Total savings owned by 174 trillion and total Islamic banking financing reached Rp 179.3 trillion (Sabadunya, 2013).

Several studies have been conducted to find out this phenomenon, including by Rudiasa (2014) which states that the low profit sharing financing in Malang sharia banks, is caused by 14 factors, namely the SDI owned by several sharia banks is not optimal in managing profit sharing financing. This financing has a higher risk than other financing, the process of filing this financing (mudharabah) is more stringent than other financing, most third party funds in short-term sharia banks. sharia banks are less than optimal in conducting promotions, profit sharing financing is still unable to compete with sale and purchase financing (murabahah) which has many advantages. sharia banks are still too focused on business and profits, profitsharing financing is quite troublesome to manage, those who participate in managing this financing are still afraid of taking big risks and tend to avoid it.

The demand for financing in Malang still controlled by murabahah, the public does not understand the ins and outs of profit 
sharing financing, the public is not interested in entrepreneurship, there is an imbalance of information between sharia banks and financing customers, and increasingly fierce competition with conventional banks forcing sharia banks to provide alternative financing with low risk such as financing murabahah. Likewise, research conducted by Aiyub (2007), Karim (2017), and Masruroh (2015) stated that most of the public did not know about sharia banking systems or products so that this situation gave less potential value to the development of sharia banks. Likewise, the intention to save on sharia banking is more on the factors of faith and income.

Based on this study, the low interest in sharia banks is still dominated by the lack of information obtained by the community equally. If it is associated with efforts that have been made by the sharia banking, sharia banks have disseminated information intensively. In addition, it is also determined by one's faith which means the higher the faith then someone wants to save money in sharia banking.

Some of the previous studies above, only illustrate that the low interest in sharia banking is only due to the lack of information from the sharia banking, and the factor of faith. Thus, the information related to the conversion of a person to sharia banking is still minimal, so that there is a gap for conducting similar research based on the existence of previous research gaps, while in theory, that consumers' decisions in using something are caused by many factors. According to Kotler and Keller (2012), consumer decisions are influenced by Culture, Social groups, Personality, Psychology, and others. So it is important to find out other factors besides the information variable.

There have not been many studies on switching barriers in banking objects. The study of switching barriers, more testing on tangible products does not cover the service sector. Thus there are still many things that have not been explored, so the novelty of this study is to find the factors that cause switching barriers to switching aside from the information factor and are tested on the service sector namely banks in South Sulawesi. To get more in-depth results, this study will use qualitative methods through interviews with the phenomenological model.

\section{LITERATURE REVIEW}

\subsection{Consumer Behavior}

Kotler and Keller (2012)and ? state that, consumer behavior is the final behavior of individuals and households in making purchases, both goods and services for personal consumption. According to Lautiainen (2015), Karedza et al. (2017), and Zhang et al. (2016) argue that consumers will make purchases several times a day.

The purchase is the only evidence of a more complex prior process that the consumer goes through in each decision taken. Thus, it can be interpreted that before making a purchase of products (goods and services) a person will go through several stages or processes before reaching the final decision, where the environment, social factors, functional needs, and the need to change are factors that underlie consumer buying behavior

\subsection{Switching barriers}

Switching barriers are factors that cause consumers / customers will not / difficult to switch, or it can also be said as an action of a company that is strived so that consumers feel regret when consumers switch to other brands / products / companies.

Switching barriers can take the form of financial, social, and psychological constraints that a customer feels when moving to a new service provider. The higher the barriers to moving, the more it will encourage customers to stick with old service providers. This opinion is in line with Chen and Japrianto (2014) that switching barrier arises as an obstacle caused by customers choosing one alternative, not only due to economic considerations, but also by psychological, social, and functional factors, so that customers continue to use products and services that when it is consumed.

According to Tung et al. (2011), switching barriers consists of three barriers namely, interpersonal relationship. Interpersonal relationships are strong personal relationships between customers and service employees. Interpersonal relationships mean psychological and social relationships that portray themselves as a caring, trustworthy and intimate company. The relationship can be established through interactions between service providers and customers, resulting in a strong bond between them and ultimately creating the formation of long-term relationships.

Is the cost incurred in the form of time, money, and energy from a customer when he moves from a competitor's product or service. Financial switching costs, which are types of switching costs that involve the loss of countable financial resources, consist of: (a) benefit loss costs is the cost of losing benefits from companies that are used by consumers today, for example losing bonuses and discounts that will not be given to new customers. (b) monetary loss costs is a one-time financial expenditure incurred to move a company outside of the expenses needed, to buy the product or service. (c) relational switching cost, that is, the type of switching costs that involve psychological discomfort and transition which results in denial of identity and breaking ties. (d) Attractive of Alternative The lack of attractive alternatives refers to the customer's perception of the extent to which viable alternatives are available in the market. The alternative attractiveness indicator used refers to the opinion of Qadri et al. (2014) the company's reputation is better than that of other companies. With the concept of switching barriers in the company, the aim is that the company can create customer loyalty and retain customers (customer retention), so that it can provide economic benefits for the company in the long run and make the company far more advanced.

\subsection{Switching Behavior}

Switching is defined as "Make a shift in or exchange of, and a change", while behavior is defined as "The action or reaction of something (Pirzada et al., 2014). Thus Switching behavior is a switching behavior from one company to another company, brands to other brands, services to other services, or from one product to another product, which is carried out by consumers for some reason. Switching behavior is a complex 
phenomenon, due to the type of consumers who prefer diversity in meeting their needs.

The most common example is seen in card ownership on mobile phones, where consumers easily move from one card to another. This transfer can be caused by incessant offers from competing products, or there are weaknesses in the product that has been purchased. According to Sun et al. (2003) displacement can be influenced by behavioral, competitive, and time factors, and the displacement can be caused by low consumer involvement in product purchases.

Several studies have examined the factors that contribute to switching behavior, summarized by Clemes et al. (2007) namely dissatisfaction with company guarantees, errors in service encounter in the retail industry, and perceptions of quality in the banking industry. While the results of the study of Clemes et al. (2007) on Bank customers in New Zealand in 2007, found that their switching behavior was influenced by Customer commitment, Service quality, Reputation, Customer satisfaction, loweducation levels, and young-age groups.

\section{RESEARCH METHODS}

This study was designed to use a mix method (qualitative and quantitative) with a sequential exploratory design that is first to conduct research with a qualitative approach with a phenomenological approach. The purpose of the qualitative approach is to find research variables, then to answer the main problem which is the cause of the community not yet shifting from conventional banking to sharia banking, then a quantitative approach using factor analysis is used.

The research subjects or informants were determined by snowball and purposive techniques. This criterion is determined by the researcher, where the chosen people are Bugis, Makassarese and Toraja. The selection of these two ethnicities to represent representation in terms of religion, given the prohibition of usury is also known in religions other than Islam, does not distinguish between sexes, in addition they are also willing to be informants. Informants collected from the snowball sampling technique will be re-selected based on cultural representation criteria, and 110 respondents will be collected representing 3 different cultures in South Sulawesi.

To obtain data for qualitative analysis, the data obtained through in-depth interviewing and not structured. Data collected in the form of: (1) data of words (verbal) and behavior (non verbal) of research subjects, (2) photographic data. This data helps provide a description of behavioral situations, and (3) statistics. This data is additional data that can be used to illustrate the research problem. While data for quantitative analysis is obtained by distributing questionnaires whose indicators come from themes summarized from the results of interviews.

To measure the variables above, a questionnaire containing statements was used, and respondents were asked to provide their responses. Each respondent's response was given a numerical score using a Likert scale with the following criteria: a. Strongly Agree (score 5), b. Agree (score 4), c. Quite Agree (score 3), d. Disagree (score 2), e. Strongly Disagree (score 1).

\section{RESULT AND DISCUSSION}

The number of respondents in this study was 110 people. The respondent data based on gender, age, religion, education, occupation, and ethnicity. The largest female respondents in this study amounted to 57 peoples, with Islam is 98 person, Christianity (9) and Catholicism (5). The most ethnic group responding to the questionnaire is Bugines 78 person, Makassar 18 person and Toraja 14 person.

From the interview results, many words are collected, where there are 20 core nodes and each word has a meaning that can be interpreted. Then the next step is to reduce data or reduce data. The reduction results show the grouping of themes as 1 (sorted by the largest number of responses):

Based on the results of qualitative data processing, 20 themes are the reason or cause of the community / customers not yet turning to sharia banking. Of the fourteen themes, other constraints have been found besides information factors that have not been maximized from sharia banking, which makes customers reluctant to switch banks and have not been exposed so far. Based on this table also seen factors inhibiting the community to switch from conventional banks to sharia banks.

The overall findings of these themes become variables that will be tested using a quantitative approach. The analytical tool used is factor analysis, where its use is to get the core factors of all the variables that have caused the conversion of conventional customers to sharia banking.

\section{The Model feasibility test of the Factor Analysis}

The model feasibility test was performed with the KaiserMeyer-Olkin (KMO) index. This method is used as a test tool to measure whether or not the number of samples is sufficient. $\mathrm{KMO}$ is an index used to test factor analysis, as Table 2.

Based on the table it can be stated that the factor analysis is appropriate to be used in analyzing data collected from the results of the interview, this can be seen from the KMO value; 0.50 and the significance value of 0,000 . After proceeding to the factor analysis stage, then of the 20 variables reduced to 7 core factors, based on an eigen value greater than 1. Based on the calculation of the Total Variance Explained, the results obtained 7 factors that have an eigen value greater than 1 , which is $5.388,2,637,1,648,1,366,1,083,1,057$, and 1,023. To find out what variables are incorporated into factors 1 to 7 , a factor rotation is carried out, as Table 3.:

Based on the results of the factor rotation, we can see the variables which are incorporated into factors 1 to factor 7, which are then given a name for the factors formed:

\section{Factor $I$}

In factor I is formed by combining 3 variables namely, X13 (Prefers Interest System), X14 (Administrative Costs and Expensive Credit to sharia banks), and X15 (Small Profit Sharing Value), this factor is called the interest fee factor.

Many people still do not really understand the production sharing system. This is evident from the results of the interview shows that the community still considers the interest system is still more profitable than profit sharing. The community feels 
Table 1: KMO and Bartlett's Test

\begin{tabular}{|c|c|c|}
\hline No & Theme & Resources \\
\hline 1 & $\begin{array}{l}\text { Lack of information about Sharia } \\
\text { banks }\end{array}$ & 51 \\
\hline 2 & $\begin{array}{l}\text { Not yet understood the revenue } \\
\text { sharing process }\end{array}$ & 19 \\
\hline 3 & $\begin{array}{l}\text { It is difficult to recognize sharia } \\
\text { products because in Arabic }\end{array}$ & 17 \\
\hline 4 & $\begin{array}{l}\text { Internet facilities are smoother in } \\
\text { conventional banks (internet bak- } \\
\text { ing and online banking }\end{array}$ & 14 \\
\hline 5 & $\begin{array}{l}\text { Difficult to find ATMs Sharia } \\
\text { banks }\end{array}$ & 14 \\
\hline 6 & $\begin{array}{l}\text { There are no Shariabanks in the } \\
\text { area }\end{array}$ & 13 \\
\hline 7 & $\begin{array}{l}\text { Sharia banks are not yet } 100 \% \\
\text { sharia }\end{array}$ & 11 \\
\hline 8 & $\begin{array}{l}\text { Salary through conventional } \\
\text { banks }\end{array}$ & 11 \\
\hline 9 & $\begin{array}{l}\text { Sharia bank services are not max- } \\
\text { imized }\end{array}$ & 11 \\
\hline 10 & $\begin{array}{l}\text { There are no product promotion } \\
\text { programs }\end{array}$ & 8 \\
\hline 11 & $\begin{array}{l}\text { Trouble if you have to open a new } \\
\text { account again }\end{array}$ & 6 \\
\hline 12 & $\begin{array}{l}\text { Sharia banks only for certain reli- } \\
\text { gions }\end{array}$ & 6 \\
\hline 13 & $\begin{array}{l}\text { The interest system is more prof- } \\
\text { itable }\end{array}$ & 5 \\
\hline 14 & $\begin{array}{l}\text { Sharia bank administration fees } \\
\text { are expensive }\end{array}$ & 3 \\
\hline 15 & Profit sharing system is small & 3 \\
\hline 16 & $\begin{array}{l}\text { Good relations have been estab- } \\
\text { lished }\end{array}$ & 2 \\
\hline 17 & $\begin{array}{l}\text { More complete conventional bank } \\
\text { services }\end{array}$ & 2 \\
\hline 18 & $\begin{array}{l}\text { The location of Sharia banks is } \\
\text { difficult to reach }\end{array}$ & 2 \\
\hline 19 & The product offered is incomplete & 2 \\
\hline 20 & $\begin{array}{l}\text { The reputation of a conventional } \\
\text { bank is better }\end{array}$ & 1 \\
\hline
\end{tabular}

Source: Analysis result.

Table 2: Kaiser-Meyer-Olkin (KMO) index and Bartlett's Test

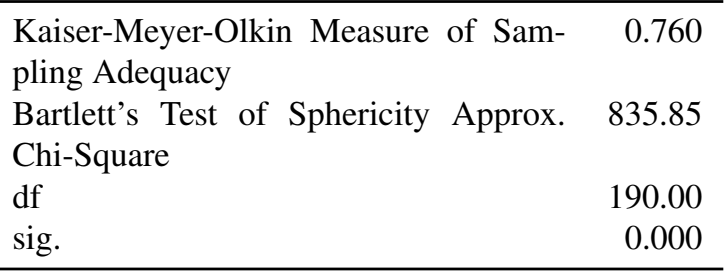

Source: Analysis result. the value sharing system is too small as a return for saving services. There is also an assumption that interest is no different from profit sharing and considers that interest is not usury. Seeing the response from the community, here it can be concluded that the community does not really understand the system for the results and what benefits are obtained with the system apart from sin or usury. One informant's statement, as follows: "Interest in sharia banks is considered low ... for very small returns".

\section{Factor II}

Variables that join in Factor II are X1 (Information Regarding sharia banks and Products are lacking), X2 (Not too understanding sharia principles), X3 (Difficulty in understanding Arabic terms), X10 (Lack of Product Promotion). This factor is called the information factor.

According to respondents, the public still survives in conventional banking due to not getting complete information related to sharia banking. The information is in the form of sharia banking. The products offered, the procedures to become customers, and what products are offered are not very clear to the public. The condition of the lack of information about sharia banks many complained by respondents who settled in the district or outside the capital city of Makassar.

"Some people do not fully understand the sharia religious principles especially about savings, the socialization of sharia banks, especially savings and credit agreements, has not yet fully reached the general public ... and the existing sharia banks are only subsidiaries of conventional banks".

\section{Factor III}

Factor III is an amalgamation of variables X6 (There are no sharia banks in the area), X18 (Locations of sharia banks are difficult to reach), X19 (products of sharia banks are incomplete). This factor is called the location factor.

The development of sharia banks was not followed by the availability of offices in rural areas or regencies in South Sulawesi. This condition is different from conventional banks, for example PT. BRI Bank which can be found to the countryside. According to respondents, if you have to spend a lot of time to reach the location of sharia banks, it is better to save at the nearest conventional bank while the same is obtained. This condition also caused many people who were not familiar with sharia banking in the regions.

\section{Factor IV}

The variables that combine in Factor IV are X16 (Good relations have been established with conventional banks), X17 (conventional banking services are more complete), X20 (conventional bank reputation is better), named the relationship and reputation factor.

The fourth factor that is the reason conventional bank customers have not moved to sharia banking is due to the reputation of conventional banks where they have been saving so far (Reputation Factor). In addition, reputation is also caused by the harmonious relationship between banks through employees 
Table 3: Rotated Component Matrix Component

\begin{tabular}{|c|c|c|c|c|c|c|c|c|c|c|c|c|c|}
\hline \multicolumn{2}{|c|}{1} & \multicolumn{2}{|c|}{2} & \multicolumn{2}{|c|}{3} & \multicolumn{2}{|c|}{4} & \multicolumn{2}{|c|}{5} & \multicolumn{2}{|c|}{6} & \multicolumn{2}{|c|}{7} \\
\hline X.13 & 0.702 & X.1 & 0.867 & X.6 & 0.769 & X.16 & 0.766 & X.7 & 0.578 & X.5 & 0.669 & X.8 & 0.841 \\
\hline X.14 & 0.804 & X.2 & 0.902 & X.18 & 0.548 & X.17 & 0.673 & X.12 & 0.741 & X.5 & 0.545 & X.11 & 0.679 \\
\hline X.15 & 0.786 & X.3 & 0.758 & X.19 & 0.668 & X.20 & 0.496 & & & X.9 & 0.777 & & \\
\hline & & X.10 & 0.502 & & & & & & & & & & \\
\hline
\end{tabular}

Source: Analysis result.

and their sermons. For customers, the bank's good reputation has been reflected in the services provided, complete facilities including online networks so that it is not difficult for them to conduct transactions even in the regions. The community considers bank employees to be nimble and alert in helping customers, in addition to the feeling of security because their banks are owned by the government. Good service causes customers to stay with the previous bank. This is supported by the statement of Sharma, (2018) that service will affect one's satisfaction so that they do not intend to switch to other brands.

\section{Factor $V$}

The variables that join the 5th factor are X7 (sharia banks are not $100 \%$ sharia) and X12 (Saria banks are only for sharia religion), called the religiosity factor.

There is an assumption that sharia banks are only for people who are Muslim, so that non-Muslim religions feel sharia banks are not their place (Religiosity Factor) This response has only been expressed by people who live in Tana Toraja which majority of non-Muslim religions. This condition is closely related to the lack of socialization on the part of sharia banks in embracing the public to glance at their products as well as sharia banking in the UK. In addition to these factors there are other reasons related to religion, namely the community feels that they do not understand exactly what the difference in interest and profit sharing is and assume that interest is open for usury. It can be seen that a person's religious understanding has an impact on banking knowledge and choices.

\section{Factor VI}

In factor VI, the variables that join are X4 (online / internet networks are not available), X5 (Difficult to get ATMs), X9 (sharia bank services are not maximized). This factor is called the product and facility factor.

Conventional banks for the community have fulfilled what they need. Many choices of products offered to the public, ranging from types of savings, credit, to other facilities in the form of salary payments. People choose to stay in conventional banking because salaries and other financial transactions are done through conventional banks. This is reinforced by their ease in queuing because it can be done through ATMs available at strategic locations. While in sharia banking complained about the lack of ATMs and if any, the location is very far away. The availability of online networks also strengthens the public to remain loyal to conventional banks when it comes to internet banking or mobile banking. "There are not many online networks to companies ... such as top-up balance transactions to credit provider companies ... only done by conventional banks and there may still be many in other sectors".

In addition, bank services if problems occur are very quickly responded by the bank. For the people of sharia bank products, there is no difference with conventional banks, even if there are differences, it is only in the names or terms used in Arabic. "The products offered are basically still the same as conventional banking products".

\section{Factor VII}

The variables that combine with factor VII are X8 (Salary and other transactions through conventional banks), X11 (troublesome if you have to switch banks). This factor is called the financial switching cost factor.

The costs in question are not only in rupiah, but also losses in terms of time and energy. People are reluctant to move because they do not want to bother if they have to open a new account again, where they have to re-prepare the necessary documents. This preparation is considered to require more time amid their busy schedule. "Moving accounts takes a day to process ... just lazily moving banks ... lazy to take care of it ...".

Based on the findings of these factors, then from this study there are 7 Factors namely Administrative and Interest Cost Factors, Minimum Information Factors, Location Factors that are difficult to reach, Reputation and Relationship Factors that have been fostered, Product Factors, and Displacement Cost Factors. From the results of this study revealed 4 of the 7 new factors that inhibit customers move, namely interests Fee Factor, location factor, religiosity factor, and product factor, which have not been found in the study of switching behavior theory that has existed so far.

\section{CONCLUSION}

There are 7 factors that are the reasons conventional bank customers have not yet moved to sharia banks, (1) interest fee Factor, (2) information factor, (3) location factor, (4) reputation factor, (5) religiosity factor, (6) product and facility factor, and (7) financial switching cost factor.

New findings in this study and focus on sharia banking are the Interest Fee Factor, Location Factor, Religiosity Factor and Product and Facility Factor. Meanwhile, the switching barrier found in conventional banking and causing loyal customers to be reluctant to move, are: (1) more favorable interest, (2) ATM and complete facilities, (3) strategic location, (4) bank's reputation, (5) large transfer costs, and (6) the discounts and gifts from conventional banks when shopping. 
The suggestion proposed for sharia banking marketers is that the findings of the research can be input for the formulation of marketing strategies with promotion and outreach different from those carried out so far and carry out to a wider market, especially areas with a majority non-Muslim population. In addition, expanding service units or offices in rural areas, and further increasing the religious approach to the community, especially the assumption that bank interest is not usury.

Suggestions for further researchers is that there are still many shortcomings, especially the lack of ethnicity and community trust (religion) included in this study due to social conditions and physical distance due to COVID 19 when the study was conducted. So it is recommended for further researchers to be able to add these items, or can also test on other service products.

\section{References}

Aiyub, 2007. Analisis Perilaku Masyarakat terhadap Keinginan Menabung dan Memperoleh Pembiayaan pada Bank Syariah di Nanggroe Aceh Darussalam. E-Mabis FE-Unimal 8 (1), 1-17.

URL: https://journal.unimal.ac.id/emabis/

Chen, Y., Japrianto, E., 2014. Pengaruh Kepuasan, Hambatan Berpindah dan Penyediaan Fasilitas Terhadap Loyalitas Konsumen di Hotel Novotel Surabaya. Jurnal Strategi Pemasaran 2 (1), 1-7.

Clemes, M. D., Gan, C., Z., L. Y., 2007. Customer switching behavior in the New Zealand banking industry. Bank and Bank Systems 2 (4), 50-65.

Hastuti, R. K., 2019. Perbankan Syariah Masih Sulit Bersaing Dengan Konvensional.

URL: https://www. cnbcindonesia.com/syariah/ 20190607133414-29-77037/perbankan-syariah-masih-sulitbersaing-dengan-konvensional

Karedza, G., Sikwila, M., Bhebhe, T. B., 2017. The Impact of Psychological Influences on Consumer Buying Behavior of SMEs' Products: A Case Study of the Manufacturing Sector in Zimbabwe. Asian Business Research Journal $2(1), 1-7$.

URL: https://doi.org/10.20448/journal.518.2017.21.1.7

Karim, K., March 2017. Kajian Mengenai Kepuasan Nasabah Bank Syariah di Kota Makassar. Fordebi 1 (2017), 1-20.

Kotler, P., Keller, K. L., 2012. Marketing Management. Prentice Hall. URL: https://doi .org/10.1080/08911760903022556

Lautiainen, T., 2015. Factors affecting consumers ' buying decision in the selection of a coffee brand.

URL: https://core.ac.uk/reader/38124382
Masruroh, A., 2015. Analisis Pengaruh Tingkat Religiusi dan Disposible Income Terhadap Minat Menabung di perbankan Syariah (Studi Kasus Mahasiswa STAIN Salatiga).

URL: http://e-repository.perpus .iainsalatiga.ac.id/666/

Pirzada, S. S., Nawas, M., Javed, M. U., A., M. Z., 2014. Which Factors Influence the Customers Switching Behavior? (Evidence from the Customers of Banking Sector of Pakistan ) Which Factors Influence the Customers Switching Behavior? ( Evidence from the Customers of Banking Sector of Pakistan). European Journal of Business and Management 6 (11), 134-142. URL: https://core.ac.uk/download/pdf/234625429.pdf

Qadri, U., Mahmood, M., Khan, S., 06 2014. Factors Affecting On Customer Retention: A Case Study of Cellular Industry of Pakistan 1, 1-22.

URL: https://www.researchgate.net/publication/303400437_ Factors_Affecting_On_Customer_Retention_A_Case_Study_of_ Cellular_Industry_of_Pakistan

Rudiasa, 2014. Analisis faktor yang mempengaruhi rendahnya pembiayaan bagi hasil di Bank Syariah Kota Malang.

URL: http://repository.um.ac.id/36757/

Sabadunya, 2013. Mari Beralih ke Bank Syariah.

URL: https://sabadunya. wordpress.com/2013/12/31/ mari-beralih-ke-bank-syariah/

Sun, B., Neslin, S. A., Srinivasan, K., 2003. Measuring the impact of Promotion on Brand Switching When Consumers are Forward Looking. Journal of Marketing Research 40 (4), 389-405.

URL: https://doi.org/10.1108/jeim.2010.08823aaa.002

Tung, G.-S., Kuo, C.-J., Kuo, Y.-T., 2011. Promotion, Switching Barriers, and Loyality. Australian Journal of Business and Management Research 1 (2). URL: http://ajbmr.com/articlepdf/ajbmr_v01n02_03.pdf

Zhang, C., Lin, Y. H., Newman, D. G., 2016. Investigating the Effectiveness of Repositioning Strategies: The Customers' Perspective. Journal of Travel and Tourism Marketing 33 (9), 1235-1250.

URL: https ://doi.org/10.1080/10548408.2015.1107018

\section{Acknowledgment}

Thank you to the Institute for Research and Development of Resources (LP2S), Indonesian Muslim University, Makassar, chaired by Prof. Dr. Syahnur Said, S.E., MS. for the opportunity and guidance in conducting research until the completion of this research report. Also to the Dean of the Faculty of Economics and Business for the motivation given, as well as the Chancellor of the Indonesian Muslim University for his trust in funding this research. 